УДК 351.858:172.15-053.67(477)]:37.091.3

https://doi.org/10.52058/2708-7530-2021-9(15)-30-50

Веприцький Роман Анатолійович здобувач вищої освіти другого (магістерського) рівняза спеціальністю 281 «Публічне управління та адміністрування», Національна Медична Академія Післядипломної освіти імені П.Л.Шупика, вул. Дорогожицька, 9, м. Київ, 04112, тел.: (095) 683-15-19, e-mail: r.vepritsky@ukr.net, https://orcid.org/0000-0003-2927-5123

\title{
ПУБЛІЧНА ПОЛІТИКА НАЦІОНАЛЬНО-ПАТРІОТИЧНОГО ВИХОВАННЯ МОЛОДІ В УКРАЇНІ ЗА 30 РОКІВ НЕЗАЛЕЖНОСТІ
}

Анотація. Поза ідеями, які вже реалізуються як елементи національнопатріотичного виховання молоді, колективна свідомість українця потерпає від великої кількості проблем. Комплекс невирішених гострих соціальних питань, питань безпеки, питань, що пов'язані з російською агресією, питань внутрішньопереміщених осіб здатні суттєво i негативно впливати на національнопатріотичну свідомість. Особливо гостро прорахунки у національнопатріотичному вихованні проявили себе під час російської агресії, коли багатьма громадянами стало усвідомлено: слабкість національно-патріотичного руху зіграло на користь агресору. Національно-патріотичне виховання стало компонентом національної безпеки. Почали напрацьовуватися необхідні докумети, відбулися вкрай необхідні зрушення.

Аналіз діяльності органів влади, а саме Президента України, Верховної Ради України, Кабінету Міністів України з метою виявлення недоліків і прорахунків у державній політиці, що стосуються національно-патріотичного виховання на сьогоднішній час, стислий огляд програм парламентських партій з метою окреслення тенденцій подальших зрушень у цьому напрямку, вибрані приклади роботи з молоддю інших держав - це спроба оцінити сучасний стан національнопатріотичного виховання молоді в Україні, та поглянути на проблему з позиції можливостей та запропонувати ідеї, що дозволять забезпечити їх досягнення.

Факт російської агресії, та спосіб, у який ця агресія була реалізована державою-агресором розкрив та показав очевідність внутрішньополітичних прорахунків поколінь українських політиків, що стосуються національнопатріотичного виховання молоді. Розуміння того, як формувалася державна політика у цій сфері, які помилки були допущені, виявлення закономірностей дозволить упередити виникнення помилок у майбутньому та планувати діяльність у цій сфері більш прагматично, раціонально та ефективно.

Ключові слова: національно-патріотичне виховання 
Veprytskyi Roman Anatoliovych Applicant for higher education of the second (master's) level in the specialty 281 "Public Administration", National Medical Academy of Postgraduate Education named after PL Shupyk, Dorogozhytska St.,9, Kyiv, 04112, tel.: (095) 683-15-19, e-mail: r.vepritsky@ukr.net, https://orcid.org/00000003-2927-5123

\title{
PUBLIC POLICY OF NATIONAL-PATRIOTIC EDUCATION OF YOUTH IN UKRAINE FOR 30 YEARS OF INDEPENDENCE
}

\begin{abstract}
Poses of ideas that have already been implemented as elements of national-patriotic education of youth, the collective consciousness of the Ukrainian suffers from a big problem. Complexes of unresolved acute social issues, security issues, issues that require interaction with Russian aggression, issues of internally displaced persons, can affect the national-patriotic consciousness. Special sharp assessments in the national-patriotic upbringing manifested themselves during the Russian aggression, while the number of citizens who became reported: the weakness of the national-patriotic movement played in favor of the aggressor. National-patriotic education has become a component of national security. Necessary documents began to be worked out, extremely necessary changes took place.

Analysis of the activities of the authorities, namely the President of Ukraine, the Verkhovna Rada of Ukraine, the Cabinet of Ministers of Ukraine in order to identify shortcomings and shortcomings in public policy relating to national and patriotic education today, a brief overview of parliamentary parties to outline trends in this The selected examples of work with the youth of other countries are an attempt to assess the current state of national-patriotic education of youth in Ukraine, and look at the problem from the standpoint of opportunities and offer ideas that will ensure their achievement.

The fact of Russian aggression and the manner in which this aggression was carried out by the aggressor state revealed and showed the obviousness of the domestic political miscalculations of generations of Ukrainian politicians concerning the national-patriotic upbringing of the youth. Understanding how the state policy was formed in this area, what mistakes were made, identifying patterns will prevent future errors and plan activities in this area more pragmatically, rationally and effectively.
\end{abstract}

Keywords: national-patriotic education

Постановка проблеми. Поза ідеями, які вже реалізуються як елементи національно-патріотичного виховання молоді, колективна свідомість українця потерпає від великої кількості проблем. Комплекс невирішених гострих соціальних питань, питань безпеки, питань, що пов'язані з російською агресією, питань внутрішньо-переміщених осіб здатні суттєво і негативно впливати на національно-патріотичну свідомість. Особливо гостро прорахунки у національнопатріотичному вихованні проявили себе під час російської агресії, коли багатьма 
громадянами стало усвідомлено: слабкість національно-патріотичного руху зіграло на користь агресору. Національно-патріотичне виховання стало компонентом національної безпеки. Почали напрацьовуватися необхідні докумети, відбулися вкрай необхідні зрушення.

Аналіз діяльності органів влади, а саме Президента України, Верховної Ради України, Кабінету Міністів України з метою виявлення недоліків і прорахунків у державній політиці, що стосуються національно-патріотичного виховання на сьогоднішній час, стислий огляд програм парламентських партій 3 метою окреслення тенденцій подальших зрушень у цьому напрямку, вибрані приклади роботи з молоддю інших держав - це спроба оцінити сучасний стан національнопатріотичного виховання молоді в Україні, та поглянути на проблему з позиції можливостей та запропонувати ідеї, що дозволять забезпечити їх досягнення.

Факт російської агресії, та спосіб, у який ця агресія була реалізована державою-агресором розкрив та показав очевідність внутрішньополітичних прорахунків поколінь українських політиків, що стосуються національнопатріотичного виховання молоді. Розуміння того, як формувалася державна політика у цій сфері, які помилки були допущені, виявлення закономірностей дозволить упередити виникнення помилок у майбутньому та планувати діяльність у цій сфері більш прагматично, раціонально та ефективно.

Виклад основного матеріалу. Единим указом Президента України Л.М. Кравчука, де згадується національно-патріотичне виховання молоді є Указ від 21.08.1993 р. № 352/9 «Про невідкладні заходи щодо посилення соціального захисту військовослужбовців та членів їх сімей» де п.п. 4 Міністерству у справах молоді та спорту України доручено розробити проект Державної програми військово-патріотичного виховання допризовників 3 метою їх підготовки до служби у Збройних Силах України [1].

31994 по 2005 роки, в указах Президента України Л.Д.Кучми тричі згадується національно-патріотичне виховання. Так, 04.01.1995 року Указом Президента України № 14/95 «Про відродження історико-культурних та господарських традицій Українського козацтва», Президент схвалює громадські ініциативи щодо державної підтримки розвитку і діяльності організацій українського козацтва та взаємодію $з$ державними органами щодо патріотичного виховання молоді [2]. Майже через 10 років опубліковано Указ Президента України; Концепція від 12.01.2004 «Про концепцію гуманітарного і соціального розвитку у Збройних Силах України». У ньому національне та патріотичне виховання згадується у контексті до військовослужбовців та членів їх сімей. Концепція підписана Головою Адміністрації Президента України В.Медведчуком [3]. Останній раз за своєї каденції Л.М.Кучма знадує про виховання молоді у контексті відношення молоді до спорту, формуванню патріотичних почуттів та позитивного іміджу держави у Указі Президента України; Доктрині від 28.09.2004 року № 1148/2004 «Про Національну доктрину розвитку фізичної культури і спорту» [4]. 
В.А.Ющенко за час свого президентства з 2005 по 2010 рр у свої указах сім разів у контексті згадував національно-патріотичне виховання молоді. Вперше в указі Президента України від 04.03.2008 № 194/2008 «Питання створення військового ліцею у селищі Батурин», стосовно виховання у молоді високої патріотичної свідомості, та у насамперед серед дітей-сиріт, дітей-військовослужбовців та дітей-учасників ліквідації наслідків Чорнобильської катастрофи [5]. Указ Президента України; Концепція від 20.03.2008 № 249/2008 «Про рішення Ради національної безпеки і оборони України від 15 лютого 2008 року «Про Концепцію реформування служби безпеки України» - питання патріотичного виховання вживаються у контексті до особового складу [6]. Указ Президента України від 04.11.2008 № 987/2008 «Про відзначення державними нагородами України активістів ветеранського руху міста Києва» стосується у тому числі внеску відзначених осіб у національно-патріотичне виховання молоді [7]. Указ Президента України від 27.11.2008 № 1102/2008 «Про функціонування та розвиток Міжнародного дитячого центру «Артек» п. 6 посилається на комплексну програму національно-патріотичного виховання та вказує Державному управлінню справами забезпечувати ії реалізацію [8].

Указом Президента України від 12.12.2008 № 1158/2008 «Про відзначення 90-ї річниці Акта злуки Української Народної Республіки і Західно-Української Народної Республіки» визначається план заходів з відзначення у 2009 році 90-ї річниці проголошення Акта злуки Української Народної Республіки і ЗахідноУкраїнської Народної республіки. Дані доручення Кабінету Миністрів України, Раді міністрів Автономної республіки Крим, обласним, Київській та Севастопольській міським державним адміністраціям, Міністерству закордонних справ України, Державному комітету телебачення і радіомовлення України щодо програми святкування та забезпечення належного фінансування святкових заходів [9]. У контексті вшанування пам'яті Володимира Івасюка в школах естетичного виховання вживаються тематичні заходи, конференції та інші події (Указ Президента України від 01.03.2009 № 111/2009 «Про вшанування пам’яті Володимира Івасюка»), де популярізується його внесок у розвиток національної культури та мистецтва [10]. Указ Президента України; Програма від 03.02.2010 № 92/2010 «Про затвердження Річної національної програми на 2010 рік 3 підготовки України до набуття членства в Організації Північноатлантичного договору» у розділі 2.1.3.1. Демократичний цивільний контроль над сектором безпеки і оборони України, згадується про можливість співпраці Міністерства оборони України 3 релігійними організаціями у контектсті задоволення релігійних потреб та національно-патріотичного виховання [11].

За президентства Віктора Януковича національно-патріотичне виховання в офіційних документах Президента України згадувалося двічі. Вперше в указі Президента України; Програма від 13.04.2011 № 468/2011 «Про затвердження Річної національної програми співробітництва Україна-НАТО на 2011 рік», як і у попередньому аналогічному документі, в контексті співробітництва релігійних 
організацій та Міністерства оборони України, та 3 аналогічною метою [12]. Вдруге, в указі Президента України; Стратегія від 25.06.2013 № 344/2013 «Про Національну стратегію розвитку освіти в Україні на період до 2021 року», у четвертому розділі «Основні напрями реалізації Національної Оновлення законодавства України у сфері освіти у частині «Забезпечення національного виховання, розвитку і соціалізації дітей та молоді» чітко не визначено національно-патріотичне виховання молоді як приорітет державної гуманітарної політики [13].

28 березня 2014 року в.о. Президента України Олександр Турчинов підписав указ № 346/2014 «Питання головного органу військового управління Національної гвардії України», в якому у п.4 пп. 17 на Головний орган військового управління Національної Гвардії України покладено організацію та забезпечення заходів 3 військово-патріотичного виховання стосовно військовослужбовців [14].

Під час перебування на посаді Президента України Петра Олексійовича Порошенка національно-патріотичному вихованню молоді було приділено набагато біше уваги. У більшості указів Президента національно-патріотичне виховання молоді згадується у контексті. Так, в указі Президента України від 16.12.2014 № 934/2014 «Про внесення змін до деяких указів Президента України», внесені зміни до Концепції допризовної підготовки і військовопатріотичного виховання молоді, схваленої Указом Президента України від 25 жовтня 2002 року № 948, що стосуються Національної гвардії України [15]. В указі Президента України від 24.03.2015 № 169/2015 «Про заходи з відзначення у 2015 році 70-ї річниці Перемоги над нацизмом у Європі та 70-ї річниці завершення другої світової війни» Кабінету Міністрів України доручено переглянути розпорядження Кабінету Міністрів України від 22 травня 2013 року № 360-p, передбачівши розвиток просвітницької діяльності 3 патріотичного виховання молоді [16].

Указ Президента України від 12.06.2015 № 334/2015 «Про заходи щодо поліпшення національно-патріотичного виховання дітей та молоді» - це перший указ президента України, що напряму стосується питань національнопатріотичного виховання молоді [17]. Зокрема, указом передбачено створення робочої групи 3 розроблення Стратегії національно-патріотичного виховання дітей та молоді на 2016-2020 роки, призначені відповідальні особи, дані доручення Кабінету Міністрів України стосовно передбачення коштів для реалізації відповідних програм, приділення особливої уваги визначеним питанням під час святкування Дня захисника України, ужиття заходів 3 осучаснення роботи навчальних закладів та інших установ, із залученням Національної академії наук України, Національної академії педагогічних наук України, та наголошено акценти стосовно залучення дітей та молоді до вивчення історичних та культурних подій та бутності незалежної України. Також в указі доручено Кабінету Міністрів України, обласним, Киїсвькій міській державній 
адміністраціям надати пропозиції щодо національно-патріотичного виховання молоді, налагодити співпрацю 3 громадськими організаціями патріотичного спрямування, та проведення під час літа 2015 року невідкладних заходів 3 національно-патріотичного виховання дітей та молоді. Міністерству оборони України доручено вжити невідкладних заходів, спрямованих на національнопатріотичне виховання молоді допризовного віку та популяризації віськової служби. Також дані доручення Міністерству інформаційної політики та Державному комітету телебачення i радіомовлення стосовно забезпечення присутності відповідної тематики у телевізійних програмах та інших засобах масової інформації.

Відзначимо, що за каденції 5-го Президента України, Петра Олексійовича Порошенка, в указах Президента України, національно патріотичне виховання молоді у контексті цих указів та по суті згадується набагато частіше, ніж в інший час. Останнім, чинним на сьогодні, Указом президента України, що по суті стосується національно-патріотичного виховання молоді є Указ Президента України; Стратегія від 18.05.2019 № 286/2019 «Про Стратегію національнопатріотичного виховання»[18]. Цим указом затверджено Стратегію національнопатріотичного виховання. Указом постановлено Кабінету Міністрів України розробити та затвердити план дій на 2020 - 2025 роки 3 реалізації Стратегії, державну цільову програму з національно-патріотичного виховання, визначено звітування щодо реалізації Стратегії. Відмічено залучення вчених та представників громадянського суспільства, визначено роль координаційних рад 3 питань національно-патріотичного виховання, утворених при місцевих державних адміністраціях та створення цільових програм 3 національнопатріотичного виховання. Стратегія національно-патріотичного виховання, затверждена цим указом, складається з дев'яти розділів.

У першому розділі «Загальні положення», національно-патріотичне виховання визначено як один 3 приорітетних напрямків діяльності держави $\mathrm{i}$ суспільства, його важливість як засобу громадянської освіти, визначається важливість поваги до державної мови як аспекту розвитку особистості. Підкреслено необхідність консолідації суспільства у розрізі сучасних викликів та необхідність постійного вдосконалення національно-патріотичного виховання. Національно-патріотичне виховання визначається як системна та цілеспрямована діяльність органів державної влади, закладів освіти, підкреслюється роль національно-патріотичного виховання як фактору зміцнення української державності та консолідуючого фактору розвитку суспільства. Основними складовими національно-патріотичного виховання визначено три напрямки: громадсько-патріотичне, військово-патріотичне та духовно-моральне. Окреслюється формування системи цінностей та свідомості навколо визначних історичних подій, роль співвітчизників у скарбниці досягнень світової цивілізації. Визначається відповідність Стратегії до положень Кнституції України, законів України «Про освіту» та інших нормативних актів за часів незалежності. 
У другому розділі «Стан і потреби національно-патріотичного виховання» актуалізуються потреби національно-патріотичного виховання, зокрема подолання наслідків тоталітарного періоду у національній свідомості, формування національного культурного простору, формування національної ідентичності, утвердження сімейних цінностей, усунення впливів ворожої пропаганди, підкреслюється потреба у постійному вдосконаленні та наданні характеру системності зусиллям щодо національно-патріотичного виховання.

Визначається мета стратегії, основні напрями досягнення мети Стратегії, сфери національно-патріотичного виховання, шляхи та механізми реалізації стратегії. Приділено увагу підвищенню кваліфікації та професійної компетенції фахівців у сфері національно-патріотичного виховання, удосконаленню нормативно-правової бази з національно-патріотичного виховання та визначено способи реалізації та моніторингу впровадження стратегії. На момент написання роботи документ є чинним.

За каденцією Президента України В.Зеленського, що триває, немає докуметів, що суттєво б доповнювали, або змінювали «Стратегію».

За даними порталу https://zakon.rada.gov.ua/ станом на 24 травня 2021 року Верховною Радою України було видано 22116 документів. За параметрами пошуку «національно-патріотичне виховання» знайдено 88 документів. У переважній більшості 3 них національно-патріотичне виховання згадується у контексті до різних сфер суспільного життя, - спорту, військової служби, культури. Серед них $\epsilon$ такі як Постанова Верховної Ради України «Про рекомендації парламентських слухань 3 питань практичної діяльності органів виконавчої влади i органів місцевого самоврядування щодо реалізації законодавства у сфері молодіжної політики» від 6 липня 1999 року N 822-XIV 3 додатком, де у п. 3.14 Кабінету Міністрів України доручено розробити проект державної програми «Патріотичне виховання молоді»[19].

У чинному Законі України «Про позашкільну освіту» 1841-III у редакції від 22.05.2021, підстава 1414-IX немає жодної згадки про національно-патріотичне виховання як системного та цілісного процесу [20].

У Постанові Верховної Ради України «Про заходи Кабінету Міністрів України щодо захисту національних інтересів держави у сферах національно свідомого і патріотичного виховання молодого покоління та забазпечення його розвитку від 22 травня 2003 року № 865-IV [21] за підписом В.Литвина вказується на відсутність системної діяльності Кабінету Міністрів та органів виконавчої влади у створенні умов щодо національно-патріотичного виховання молоді та рекомендується розробити проект закону України про затвердження Національної програми патріотичного виховання молоді. Програма «Діти України», що згадується у Постанові, не містить жодних пов'язаних та таких, що стосуються національно-патріотичного виховання даних.

Постанова від 18 вересня 2003 року № 1200-IV, де йдеться про національнопатріотичне виховання молоді має назву «Про 85-ту річницю ВЛКСМ та 
державну підтримку молодіжного руху». В ній йдеться про вшанування діяльності ВЛКСМ. Підписано В.Литвином.

Чинний донині документ 1281-IV в редакції від 28.01.2005, підстава 2353-IV Закон України «Про Загальнодержавну програму підтримки молоді на 2004-2008 роки» в преамбулі згадує про важливість національно-патріотичного виховання, та у цілому містить опис функцій різних установ, що стосуються молоді [23].

Постанова Верховної Ради України від 22 березня 2007 року№ 816-V «Про рекомендації парламенських слухань про становище молоді в Україні (щодо підтримки молодої сім’і, посилення соціального захисту дітей та молоді у 20012006 роках)» містить єдину згадку про національно-патріотичне виховання у розрізі позанавчальної виховної роботи, яку потрібно удосконалити [24].

Документом 2992-VI від 03.02.2011 року Верховною Радою України прийнята постанова «Про Рекомендації парламентських слухань про становище молоді в Україні «Молодь та здоровий спосіб життя» Кабінету Міністрів України доручено розробити Загальнодержавну цільову соціальну програму патріотичного виховання населення та вжити заходів 3 поліпшення роботи 3 патріотичного та іншого виховання дітей та молоді та утвердження здорового способу життя [25].

Чинний Закон України «Про вищу освіту» № 1556-VII у редакції від 23.04.2021, підстава 1357-IX та підставою 1369-IX з редакцією, що відбудеться 01.09.2021, у розділі VI «Заклади вищої освіти», статті 26 п. 4) одним з основних завдань закладу вищої освіти визначено формування особистості шляхом патріотичного виховання [26].

Постанова Верховної Ради України «Про вшанування героїв АТО та вдосконалення національно-патріотичного виховання дітей та молоді № 373-VIII від 12 травня 2015 року [27] вказує на необхідність поширення правдивої інформації стосовно обставин збройної агресії Російської Федерації проти України, окупації Криму, підтримки Російською Федерацією збройного конфлікту на Донбасі та намагання дестабілізації ситуації в інших регіонах України. Кабінету Міністрів України рекомендується, зокрема, організувати системне збирання та поширення інформації про героїчні вчинки воїнів учасників АТО, волонтерів та громадян, які зробили значний внесок у зміцнення обороноздатності України, спільно з іншими інститутами системно збирати та вести облік доказів російської агресії та оприлюднювати їх, розробити методичні рекомендації щодо представлення інформації, пов'язаної з окупацією Криму, забезпечити представлення означеної інформації у тому числі за кордоном, місцевим державним адміністраціям рекомендовано вжити аналогічних заходів та передбачено проінформувати Верховну Раду України про вжиті заходи.

Заслуговує уваги також постанова Верховної Ради України «Про Рекомендації парламентських слухань про становище молоді в Україні на тему: «Ціннісні орієнтації сучасної української молоді» від 23 лютого 2017 року № 1908-VIII [28] за головуванням А.Парубія. В ній схвалюються Рекомендації 
парламентських слухань про становище молоді в Україні на тему «Ціннісні орієнтації сучасної української молоді». Окреслимо вибрані тези 3 цих Рекомендацій, що стосуються національно-патріотичного виховання молоді. Тут підкреслюється, зокрема, необхідність формування громадянської ідентичності молоді як невід'ємної складової державотворчих процесів та розвитку суспільства. Рекомендується:

- Президенту України розглянути доцільність відновлення діяльності Національної ради з питань молодіжної політики при Президентові України.

- Верховній Раді України сприяти підтримці децентралізації роботи 3 молоддю, запровадження стандардів у відповідності до практик Ради Свропи по роботі 3 молоддю, заходів громадських об’єднань щодо національнопатріотичного виховання.

- Кабінету Міністрів України - розробити та затвердити державну цільову программу національно-патріотичного виховання на 2018 - 2022 роки, вжити заходів для створення механізмів міжвідомчої та міжсекторальної взаємодії при проведенні заходів державної молодіжної політики та у сфері національнопатріотичного виховання. Також, з метою посилення заходів із забезпечення формування ціннісних орієнтирів молоді одним із приорітетних напрямків в реалізації державної молодіжної політики визначено національно-патріотичне виховання молоді. Передбачено збільшення частки телепрограм, що створюються за державним замовленням, щодо формування в української молоді патріотизму та національної свідомості на історичних прикладах, та викликах сучасності.

- Окремим параграфом Міністерству молоді та спорту України доручено сприяти популяризації українських суспільно-державницьких цінностей, зокрема самобутності, соборності, волі і гідності Українського народу, та формування на їх основі національно-патріотичного світогляду дітей та молоді, виробленню критеріїв та показників формування національно-патріотичного світогляду 3 позиції науки.

- Міністерству освіти і науки доручено зокрема вдосконалити роботу у тому числі з патріотичного виховання та формування у них відповідних моральних цінностей, посилити виховну роботу 3 питань формування національної самосвідомості, рекомендовано розробити методичні рекомендації щодо виконання Державаного Гімну України та підняття Державного Прапора України у навчальних та позашкільних закладах щонайменше перед початком кожної чверті або семестру 3 метою вироблення поваги до державної символіки, залучення молоді до заходів поширення світогляду у розрізі сучасних викликів Української держави.

- Міністерству культури України доручено сприяти створенню творів мистецтва, що утверджують у тому числі національно-патріотичні цінності, поповнення бібліотечного фонду національно-патріотичною літературою, системному оновленню музеїв 3 акцентом на самовизначення українського народу, та ідеали національної соборності та державності. 
- Місцевим органам виконавчої влади та органам місцевого самоврядування доручено розробити місцеві програми національно-патріотичного виховання.

Політичнна партія «Слуга народу», що сформувала у Верховній Раді України IX скликання фракцію з 244 місцями, у своїй програмі, що опублікована на офіційному сайті партії https://sluga-narodu.com/program/ [29] останнім параграфом «Національна ідентичність і громадянська злагода» ставить за мету, зокрема, запровадження гуманітарної політики, що сприяє культурному, громадянському та духовному об'єднанню громадян України та створення системи підтримки української мови та культури за допомогою фіскальних стимулів і пріорітетного державного фінансування.

Друга за чисельністю депутатська фракція партії «Опозиційна платформа за життя», за даними офіційного сайту одноіменної партії https://zagittya.com.ua/ua/page/programma.html [30] у своїй програмі не робить акцентів, що стосуються національно-патріотичного виховання молоді, у тому числі і засобами освіти. Аналогічно таких акцентів не встановлює і Всеукраїнське об'єднання «Батьківщина» 3 одноіменною фракцією 325 місцями у Верховній Раді України (https://ba.org.ua/programm/) [31].

Партія Европейська солідарність утворює у Верховній Раді України IX скликання фракцію з 27 депутатських місць. Програма політичної партії Европейська солідарність https://eurosolidarity.org/wpcontent/uploads/2020/02/Programa_31_05_2019.pdf [32] містить чисельні акценти, що стосуються культурної та національної ідентичності, та окремим пунктом 7.1. «Національно-патріотичне виховання», де вказує на необхідність розвитку міжвідомчої програми дій із заходів національно-патріотичного виховання.

Партія «Голос» представлена у Верховній Раді України 20 депутатами, що формують одноіменну фракцію. На свойому офіційному сайті у програмі партії не виявлено згадок про національно-патріотичне виховання, або таких, що прямо вказують на його необхідність (https://goloszmin.org/program [33].

Депутатська група партії «За майбутнє», що складається 322 депутатів (https://zamajbutne.com.ua/) [34] не містить програми партії на свойому офіційному сайті.

Одже, очікування стосовно ініциатив та перспектив за впливовим представництвом нинішніх парламентських партій зрушень, що стосуються удосколалення державної політики 3 національно-патріотичного виховання молоді, безпідставні.

Кабінет Міністрів України за увесь період незалежності видав 168 документів, де напряму, або в контексті згадуються як завдання або необхідність національно-патріотичного виховання. Розглянемо деякі з них, які є чинними на сьогоднішній час.

Постанова Кабінету Міністрів України від 22 липня 2015 р. № 524 «Про утворення Міжвідомчої комісії $з$ питань національно-патріотичного виховання» [35], із змінами, остання № 21 від 13.01.2021, утворено Міжвідомчу комісію з питань 
національно-патріотичного виховання, 3 широким складом та затвердженим даною постановою Положенням, за підписом Прем’єр-міністра А.Яценюка.

Розпорядження № 1400-р від 25 грудня 2015 р. «Про затвердження заходів щодо національно-патріотичного виховання молоді на 2016 рік» [36] містить план, виконання якого доручено Міністерству молоді та спорту, Міністерству освіти і науки, Міністерству оборони, Міністерству соціальної політики, Міністерству культури, обласним та у м.Києві міській державним адміністраціям, у якому удосконалення нормалтивно-правової бази у сфері національнопатріотичного виховання, розробка проекта цільової програми національнопатріотичного виховання, розробка типового положення про раду 3 питань національно-патріотичного виховання при місцевих адміністраціях, комплексні освітньо-виховні, інформаційні, культурні та міжнародні заходи, що ставлять за мету власне національно-патріотичне виховання молоді. Розпоряднення підписано за прем’єрства А.Яценюка.

Розпорядження № 898-р від 30 листопада 2016 р. «Про затвердження плану заходів щодо національно-патріотичного виховання молоді на 2017 рік» [37], аналогічно до попереднього, містить план конкретних заходів, виконання якого доручено Міністерствам, Кї̈вькій та обласним державним адміністраціям. Розпоряднення підписано за прем'єрства В.Гройсмана.

Постанова № 999 від 7 грудня 2016 р. «Про затвердження Типового положення про координаційну раду 3 питань національно-патріотичного виховання при місцевій державній адміністрації» [38] містить відповідне типове положення та містить рекомендацію Київській міскій та обласним державним адміністраціям затвердити положення про зазначені ради.

Постанова Кабінету Міністрів України від 9 жовтня 2020 р. № 932 «Про затвердження плану дій щодо реалізації Стратегії національно-патріотичного виховання на 2020-2025 роки» [39] містить одноіменний план та зобов'язує міністерства, інші центральні органи виконавчої влади, обласні, Київську міську державну адміністрацію забезпечити його своєчасне виконання та надавати щороку Міністерству молоді та спорту інформацію про стан виконання. План дій щодо реалізації Стратегії національно-патріотичного виховання на 2020-2025 роки містить 33 пункти 3 визначеними заходами, строки виконання цих заходів та установи, відповідальні за його виконання. Зокрема, п. 2 передбачено удосконалення нормативно-правової бази щодо національно-патріотичного виховання шляхом передбачення під час розроблення Державних стандартів базової середньої та профільної освіти, програм, підручників та навчальнометодичних посібників, методичних рекомендацій засад виховання патріотизму, поваги до культурних цінностей Українського народу, його історико-культурного надбання і традицій. Приділено увагу упорядкуванню та вдосконаленню системи військово-патріотичного виховання. П. 8, зокрема, передбачається надання допомоги закладам освіти в організації та проведенні навчально-польових зборів та інших організаційно-масових заходів військово-патріотичного спрямування. 
Визначено заходи 3 організації та координації інформаційно-просвітнцької роботи у сфері інформаційно-просвітницької роботи у сфері національнопатріотичного виховання. Визначено заходи з забезпечення належної організації науково-дослідницької та методичної роботи у сфері національно-патріотичного виховання. Зокрема, п.23 передбачає вивчення вітчизняних та зарубіжних сучасних виховних систем, узагальнення та поширення найкращого досвіду 3 національно-патріотичного виховання. Визначено заходи 3 забезпечення скоординованої діяльності у сфері національно-патріотичного виховання. Зокрема, п. 30 передбачено проведення у закладах освіти інформаційнопросвітницьких та виховних заходів з питань безпеки, домедичної підготовки, підвищення престижу військової служби.

Розпорядження Кабінету Міністрів України від 9 жовтня 2020 р. № 1233-p «Про схвалення концепції Державної цільової соціальної програми національнопатріотичного виховання на період до 2025 року» [40] схвалює Концепцію Державної цільової соціальної програми національно-патріотичного виховання на період до 2025 року. Державна цільова соціальна програма національнопатріотичного виховання на період до 2025 року (далі - Програма), зокрема, визначає підгрунтя та проблематику, яка вимагає розв'язання. У Програмі визначаються загрози, а саме за результатами соціологічних опитувать простежено ідентифікатор «громадянин України» по регіонах України та вказано розбіжності самоідентифікації у різних регіонах, простежено ситуацію 3 використанням української мови, вказується на низьку готовність відстоювати територіальну цілісність України із зброєю в руках, низьких рівень сформованої цінності державної символіки, низьке залучення населення до національнопатріотичних громадських формувань. Визначається «потреба у впровадженні цілісної загальнодержавної політики національно-патріотичного виховання щодо формування української громадянської ідентичності, що сприятиме єдності та консолідації українського суспільства». Підкреслено потреба міжгалузевої взаємодії. Аналізуються причини виникнення проблем та обгрутовується необхідність іiі розв'язання програмним методом. Однією з причин виникнення проблем називається «відсутність протягом періоду існування незалежної України загальнодержавної політики, довгострокового, послідовного, конструктивного плану дій та комплексу взаємозв'язаних завдань і заходів із проведенням постійного аналізу та моніторингу в процесі їх реалізації у сфері національно-патріотичного виховання i формування громадянської ідентичності». Підкреслюється необхідність «здійснити перехід до комплексної моделі державної політики національно-патріотичного виховання». Метою програми визначається «удосконалення та розвиток цілісної загальнодержавної політики національно-патріотичного виховання шляхом формування та утвердження української громадянської ідентичності на основі єдиних суспільнодержавних (національних) цінностей (самобутність, воля, соборність, гідність) і загальнолюдських цінностей, принципів любові і гордості за власну державу, іiі

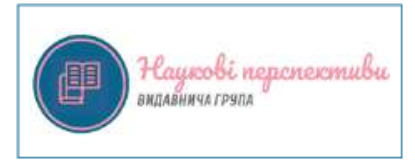


історію, мову, здобутки та досягнення у сфері культури, економіки, науки, спорту, дієве сприяння органам державної влади та органам місцевого самоврядування в захисті і охороні національної державності Українського народу, готовність до захисту державної незалежності і територіальної цілісності України, усвідомлення громадянського обов'язку із розвитку успішної країни та забезпечення власного благополуччя в ній». На основі порівняльного аналізу визначено оптимальний варіант розв'язання проблеми. Вказується необхіднисть комплексних дій. Порівнюється варіант «застосування традиційного механізму організації роботи у сфері національно-патріотичного виховання - на основі діючої управлінської вертикалі» та оптимальний, що «передбачає формування цілісної загальнодержавної політики національно-патріотичного виховання, в основі якої є поєднання управлінської вертикалі 3 інститутами громадянського суспільства, в тому числі через роботу дорадчого органу, який координує розвиток сфери національно-патріотичного виховання на міжвідомчому рівні, координаційних рад з питань національно-патріотичного виховання при місцевих держадміністраціях, центрів національно-патріотичного виховання 3 метою формування української громадянської ідентичності».

Програма окреслює шляхи i способи розв'язання проблеми та встановлюються строки виконання Програми. Встановлюються пріоритети. Строк виконання Програми: з 2020 до 2025 року».

Висновки. Минуло 30 років 3 відновлення незалежності Україною. Близько 90 відсотків громадян підтримали Акт про проголошення незалежності, i серед них були такі, кому на той момент виповнилося 18 років. Зараз їх вік наближується до 50. Ціле покоління українців будували свое життя, створювали сім’ї, виховували дітей, і це все - за час, коли Україна була незалежною. В той же час, виходячи 3 огляду діяльності президента України, Верховної Ради України, Кабінету Міністрів України, не було ані формалізації загроз, ані постановки цілей, ані вироблення кроків стосовно національно-патріотичного виховання. Ліше зараз, через 6 років після Революції гідності, ми маємо такі документи як Концепція, Стратегія та План національно-патріотичного виховання, які претендують бути названим системними, комплексними, та такими, що хоча б частково, але все ж відповідають, сучасним викликам.

Першим документом Президента України, що напряму стосується питань національно-патріотичного виховання є Указ Президента України від 12.06.2015 № 334/2015 «Про заходи щодо поліпшення національно-патріотичного виховання дітей та молоді» [17]. Цим указом створюється робоча група 3 розроблення Стратегії національно-патріотичного виховання дітей та молоді на 2016 - 2020 роки. I лише через 4 роки ми бачимо Указ Президента Ураїни від 18.05.2019 № 286/2019 «Про стратегію національно-патріотичного виховання», де затверджується відповідна Стратегія да доручається Кабінету Міністрів України розробити та затвердити «План дій на 2020 - 2025 роки з реалізації Стратегії» [18]. I перший i другий докумети видані за президентства Петра Порошенка. Примітно, що 
другий названий документ виданий за два дні до закінчення його каденції.

Першою спробою Верховної Ради України просунутися у цьому напрямку, та такою, що не знайшла реалізації, можно вважати Постанову № 865-IV від 22 травня 2003 року «Про заходи Кабінету Міністрів України щодо захисту національних інтересів держави у сферах національно свідомого і патріотичного виховання молодого покоління та забезпечення його розвитку» [21], де до Кабінету Міністрів апелюється про відсутність системної діяльності у цьому напрямку та пропонується розробити відповідний закономпроект. Через 12 років, вже після початку російської агресії Верховна Раді України публікує Постанову № 373-VIII від 12 травня 2015 року «Про вшанування героїв АТО та вдосконалення національно-патріотичного виховання дітей та молоді» [27], де мова ще не йде про системність, але вже визначені акценти та даються конкретні доручення Кабінету Міністрів України. Наступним важливим докуметом, виданим Верховною Радою України відмітим Постанову від 23 лютого 2017 року № 1908-VIII «Про рекомендації парламентських слухань про становище молоді в Україні на тему «Ціннісні орієнтації сучасної молоді» [28], де вперше ми бачимо комплексний підхід та системність зусиль 3 національно-патріотичного виховання. До сьогодні інших визначальних документів Верховною Радою України не було видано, та виходячи з огляду програм парламентських партій, що нині представлені у Верховній Раді України, малоймовірно, що такі документи будуть створені.

Цілеспрямована діяльність Кабінету Міністрів України, що стосується питань національно-патріотичного виховання по суті починається 3 Постанови Кабінету Міністрів Українивід від 22 липня 2015 р. № 524 «Про утворення Міжвідомчої комісії з питань національно-патріотичного виховання» [35] де створюється міжвідомча комісія з питань національно-патріотичного виховання. Далі ми бачимо Розпорядження № 1400-p від 25 грудня 2015 р. «Про затвердження заходів щодо національно-патріотичного виховання молоді на 2016 рік» [36] де міститься план заходів з національно-патріотичного виховання, потім Розпорядження № 898-р від 30 листопада 2016 р. «Про затвердження плану заходів щодо національно-патріотичного виховання молоді на 2017 рік» [37], де аналогічно до зазначеного вище є план, який можна оцінити як комплексний, але все ще не системний. Відмітими також Постанова № 999 від 7 грудня 2016 р. «Про затвердження Типового положення про координаційну раду з питань національно-патріотичного виховання при місцевій державній адміністрації» [38] де міститься типове положення, і лише 9 жовтня 2020 р. видана Постанова Кабінету Міністрів України № 932 «Про затвердження плану дій щодо реалізації Стратегії національно-патріотичного виховання на 2020-2025 роки» [39], яку можна охарактеризувати як системну у напрямку національно-патріотичного виховання. Останнім значущим і чинним є Розпорядження Кабінету Міністрів України від 9 жовтня 2020 р. № 1233-р «Про схвалення концепції Державної цільової соціальної програми національно-патріотичного виховання на період до 
2025 року» [40], де у концептуальному форматі визначено підгрунтя та проблематику, яка вимагає розв’язання.

Якщо поглянути на діяльність центральних органів влади 3 питань національно-патріотичного виховання по суті з боку їх хронології, то картина буде виглядате так:

•Постанова Верховної Ради України № 865-IV від 22 травня 2003 року «Про заходи Кабінету Міністрів України щодо захисту національних інтересів держави у сферах національно свідомого і патріотичного виховання молодого покоління та забезпечення його розвитку» [21];

•Постанова Кабінету Міністрів України № 373-VIII від 12 травня 2015 року «Про вшанування героїв АТО та вдосконалення національнопатріотичного виховання дітей та молоді» [27];

•Указ Президента України від 12.06.2015 № 334/2015 «Про заходи щодо поліпшення національно-патріотичного виховання дітей та молоді» [17];

•Постанова Кабінету Міністрів України від від 22 липня 2015 р. № 524 «Про утворення Міжвідомчої комісії з питань національно-патріотичного виховання» [35];

•Розпорядження № 1400-р від 25 грудня 2015 р. «Про затвердження заходів щодо національно-патріотичного виховання молоді на 2016 рік» [36];

•Розпорядження № 898-р від 30 листопада 2016 р. «Про затвердження плану заходів щодо національно-патріотичного виховання молоді на 2017 рік» [37];

-Постанова № 999 від 7 грудня 2016 р. «Про затвердження Типового положення про координаційну раду з питань національно-патріотичного виховання при місцевій державній адміністрації» [38];

•Постанова від 23 лютого 2017 року № 1908-VIII «Про рекомендації парламентських слухань про становище молоді в Україні на тему «Ціннісні орієнтації сучасної молоді» [28];

•Указ Президента Ураїни від 18.05.2019 № 286/2019 «Про стратегію національно-патріотичного виховання», де затверджується відповідна Стратегія да доручається Кабінету Міністрів України розробити та затвердити «План дій на 2020 - 2025 роки з реалізації Стратегї̈ [18];

•Постанова Кабінету Міністрів України № 932 від 9 жовтня 2020 р. «Про затвердження плану дій щодо реалізації Стратегії національнопатріотичного виховання на 2020-2025 роки» [39];

-Розпорядження Кабінету Міністрів України від 9 жовтня 2020 р. № 1233-р «Про схвалення концепції Державної цільової соціальної програми національно-патріотичного виховання на період до 2025 року» [40].

Перспективи. Очевидно, проблематика національно-патріотичного виховання набула системної діяльності з боку центральних органів влади України лише останні два роки. Очевидно також, що ця діяльність не є випереджальною, а такою, що намагається реагувати на події та обставини, які вже виникли, та 
заповнити собою роки бездіяльності. Також очевидна вкрай повільна динаміка стосовно національно-патріотичного виховання. Документи створюються роками та інколи десятками років, немає наступності, немає прогнозування, та відповідного аналізу, упередження майбутніх викликів та реакції на них. В цілому діяльність органів влади можна охарактеризувати як такою, що наздоганяє втрачене, а не планує майбутнє, та такими, що виходять із запіздненням у умовних 30 років. Якщо припустити, що останні документи, такі як Концепція, Стратегія та План дій, були б випущені та хоча б частково реалізовані незабаром після відновлення незалежності, то картина була б зовсім іншою. Важко собі уявити, але покоління, виховані 30 роками відповідної державної політики, зовсім по іншому складали б опір російській агресії, зовсім по-іншому бачили б своє майбутнє як у розрізі зовнішньої та внутрішньої державної політики, так і в цілому бачили б по іншому своє місце у сучасному світі.

\section{Лimepamypa:}

1. Про невідкладні заходи щодо посилення соціального захисту військовослужбовців та членів їх сімей, Указ Президента України від 21.08.1993 № 352/93.

2. Про відродження історико-культурних та господарських традицій Українського козацтва, Указ Президента України від 04.01.1995 № 14/95.

3. Про концепцію гуманітарного і соціального розвитку у Збройних Силах України, Указ Президента України; Концепція від 12.01.2004 № 28/2004.

4. Про Національну доктрину розвитку фізичної культури і спорту, Указ Президента України; Доктрина від 28.09.2004 року № 1148/2004.

5. Питання створення військового ліцею у селищі Батурин, Указ Президента України від 04.03.2008 № 194/2008.

6. Про рішення Ради національної безпеки і оборони України від 15 лютого 2008 року «Про Концепцію реформування служби безпеки України», Указ Президента України; Концепція від 20.03.2008 № 249/2008.

7. Про відзначення державними нагородами України активістів ветеранського руху міста Києва, Указ Президента України від 04.11.2008 № 987/2008.

8. Про функціонування та розвиток Міжнародного дитячого центру «Артек», Указ Президента України від 27.11.2008 № 1102/2008.

9. Про відзначення 90-ї річниці Акта злуки Української Народної Республіки і ЗахідноУкраїнської Народної Республіки, Указ Президента України від 12.12.2008 № 1158/2008.

10. Про вшанування пам'яті Володимира Івасюка, Указ Президента України від 01.03.2009 № 111/2009.

11. Про затвердження Річної національної програми на 2010 рік з підготовки України до набуття членства в Організації Північноатлантичного договору, Указ Президента України; Програма від 03.02.2010 № 92/2010.

12. Про затвердження Річної національної програми співробітництва Україна-НАТО на 2011 рік, Указ Президента України; Програма від 13.04.2011 № 468/2011.

13. Про Національну стратегію розвитку освіти в Україні на період до 2021 року, Указ Президента України; Стратегія від 25.06.2013 № 344/2013.

14. Питання головного органу військового управління Національної гвардії України, Указ Президента України; Положення від 28.03.2014 № 346/2014. 
15. Указ Президента України від 16.12.2014 № 934/2014 «Про внесення змін до деяких указів Президента України».

16. Указ Президента України від 24.03.2015 № 169/2015 «Про заходи з відзначення у 2015 році 70-ї річниці Перемоги над нацизмом у Європі та 70-ї річниці завершення другої світової війни».

17. Указ Президента України від 12.06.2015 № 334/2015 «Про заходи щодо поліпшення національно-патріотичного виховання дітей та молоді».

18. Указ Президента України; Стратегія від 18.05.2019 № 286/2019 «Про Стратегію національно-патріотичного виховання».

19. Постанова Верховної Ради України «Про рекомендації парламентських слухань 3 питань практичної діяльності органів виконавчої влади і органів місцевого самоврядування щодо реалізації законодавства у сфері молодіжної політики» від 6 липня 1999 року N 822-XIV.

20. Закон України «Про позашкільну освіту» 1841-III у редакції від 22.05.2021, підстава 1414-IX.

21. Постанова Верховної Ради України «Про заходи Кабінету Міністрів України щодо захисту національних інтересів держави у сферах національно свідомого і патріотичного виховання молодого покоління та забезпечення його розвитку від 22 травня 2003 року № 865-IV.

22. Постанова від 18 вересня 2003 року № 1200-IV «Про 85-ту річницю ВЛКСМ та державну підтримку молодіжного руху.

23. Документ 1281-IV в редакції від 28.01.2005, підстава 2353-IV Закон України «Про Загальнодержавну програму підтримки молоді на 2004-2008 роки.

24. Постанова Верховної Ради України від 22 березня 2007 року№ 816-V «Про рекомендації парламенських слухань про становище молоді в Україні (щодо підтримки молодої сім'ї, посилення соціального захисту дітей та молоді у 2001-2006 роках)».

25. Постанова 2992-VI від 03.02.2011 Верховної Ради України «Про Рекомендації парламентських слухань про становище молоді в Україні «Молодь та здоровий спосіб життя».

26. Закон України «Про вищу освіту» № 1556-VII у редакції від 23.04.2021.

27. Постанова Верховної Ради України «Про вшанування героїв АТО та вдосконалення національно-патріотичного виховання дітей та молоді» № 373-VIII від 12 травня 2015 року.

28. Постанова Верховної Ради України «Про Рекомендації парламентських слухань про становище молоді в Україні на тему: «Ціннісні орієнтації сучасної української молоді» від 23 лютого 2017 року № 1908-VIII.

29. https://sluga-narodu.com/program/.

30. https://zagittya.com.ua/ua/page/programma.html

31. https://ba.org.ua/programm/

32. https://eurosolidarity.org/wp-content/uploads/2020/02/Programa_31_05_2019.pdf

33. https://goloszmin.org/program

34. https://zamajbutne.com.ua/

35. Постанова Кабінету Міністрів України від 22 липня 2015 р. № 524 «Про утворення Міжвідомчої комісії з питань національно-патріотичного виховання».

36. Розпорядження № 1400-р від 25 грудня 2015 р. «Про затвердження заходів щодо національно-патріотичного виховання молоді на 2016 рік».

37. Розпорядження № 898-р від 30 листопада 2016 р. «Про затвердження плану заходів щодо національно-патріотичного виховання молоді на 2017 рік».

38. Постанова № 999 від 7 грудня 2016 р. «Про затвердження Типового положення про координаційну раду з питань національно-патріотичного виховання при місцевій державній адміністрації».

39. Постанова Кабінету Міністрів України від 9 жовтня 2020 р. № 932 «Про затвердження плану дій щодо реалізації Стратегії національно-патріотичного виховання на 2020-2025 роки». 
40. Розпорядження Кабінету Міністрів України від 9 жовтня 2020 р. № 1233-р «Про схвалення концепції Державної цільової соціальної програми національно-патріотичного виховання на період до 2025 року».

\section{References:}

1. Ukaz Prezidenta Ukraïni «Pro nevidkladni zahodi shhodo posilennja social'nogo zahistu vijs'kovosluzhbovciv ta chleniv ïh simej » [Decree of the President of Ukraine «On urgent measures to strengthen the social protection of servicemen and members of their families »]. (n.d.). zakon.rada.gov.ua. Retrieved from https://zakon.rada.gov.ua/laws/show/352/93 [in Ukrainian].

2. Ukaz Prezidenta Ukraïni «Pro vidrodzhennja istoriko-kul'turnih ta gospodars'kih tradicij Ukraïns'kogo kozactva», [Decree of the President of Ukraine «On the revival of historical, cultural and economic traditions of the Ukrainian Cossacks »]. (n.d.). zakon.rada.gov.ua. Retrieved from https://zakon.rada.gov.ua/laws/show/14/95\#Text. [in Ukrainian].

3. Ukaz Prezidenta Ukraïni «Pro koncepciju gumanitarnogo i social'nogo rozvitku u Zbrojnih Silah Ukraïni », [Decree of the President of Ukraine "On the concept of humanitarian and social development in the Armed Forces of Ukraine »]. (n.d.). zakon.rada.gov.ua. Retrieved from https://zakon.rada.gov.ua/laws/show/28/2004 [in Ukrainian].

4. Ukaz Prezidenta Ukraïni «Pro Nacional'nu doktrinu rozvitku fizichnoï kul'turi i sportu», [Decree of the President of Ukraine « On the National Doctrine of Development of Physical Culture and Sports»]. (n.d.). zakon.rada.gov.ua. Retrieved from https://zakon.rada.gov.ua/laws/show/ 1148/2004\#Text. [in Ukrainian].

5. Ukaz Prezidenta Ukraïni «Pitannja stvorennja vijs'kovogo liceju u selishhi Baturin », [Decree of the President of Ukraine «The issue of establishing a military lyceum in the village of Baturyn »]. (n.d.). zakon.rada.gov.ua. Retrieved from https://zakon.rada.gov.ua/laws/show/ 194/2008\#Text. [in Ukrainian].

6. Ukaz Prezidenta Ukraïni «Pro rishennja Radi nacional'noï bezpeki i oboroni Ukraïni vid 15 ljutogo 2008 roku «Pro Koncepciju reformuvannja sluzhbi bezpeki Ukraïni»», [Decree of the President of Ukraine « On the Decision of the National Security and Defense Council of Ukraine of February 15, 2008 "On the Concept of Reforming the Security Service of Ukraine"»]. (n.d.). zakon.rada.gov.ua. Retrieved from https://zakon.rada.gov.ua/laws/show/249/2008\#Text. [in Ukrainian].

7. Ukaz Prezidenta Ukraïni «Pro vidznachennja derzhavnimi nagorodami Ukraïni aktivistiv veterans'kogo ruhu mista Kieva », [Decree of the President of Ukraine « On the awarding of state awards of Ukraine to activists of the veteran movement of the city of Kyiv»]. (n.d.). zakon.rada.gov.ua. Retrieved from https://zakon.rada.gov.ua/laws/show/987/2008\#Text. [in Ukrainian].

8. Ukaz Prezidenta Ukraïni «Pro funkcionuvannja ta rozvitok Mizhnarodnogo ditjachogo centru «Artek», [Decree of the President of Ukraine « On the functioning and development of the International Children's Center "Artek", »]. (n.d.). zakon.rada.gov.ua. Retrieved from https://zakon.rada.gov.ua/laws/show/1102/2008\#Text. [in Ukrainian].

9. Ukaz Prezidenta Ukraïni «Pro vidznachennja 90-ï richnici Akta zluki Ukraïns'koï Narodnoï Respubliki i Zahidno-Ukraïns'koï Narodnoï Respubliki », [Decree of the President of Ukraine « On the celebration of the 90th anniversary of the Act of Unification of the Ukrainian People's Republic and the Western Ukrainian People's Republic »]. (n.d.). zakon.rada.gov.ua. Retrieved from https://zakon.rada.gov.ua/laws/show/1158/2008\#Text [in Ukrainian].

10. Ukaz Prezidenta Ukraïni «Pro vshanuvannja pam'jati Volodimira Ivasjuka iki », [Decree of the President of Ukraine « On honoring the memory of Volodymyr Ivasyuk »]. (n.d.). zakon.rada.gov.ua. Retrieved from https://zakon.rada.gov.ua/laws/show/111/2009\#Text [in Ukrainian].

11. Ukaz Prezidenta Ukraïni « Pro zatverdzhennja Richnoï nacional'noï programi na 2010 rik z pidgotovki Ukraïni do nabuttja chlenstva v Organizaciï Pivnichnoatlantichnogo dogovoru », [Decree of the President of Ukraine « On approval of the Annual National Program for 2010 on preparation of 
Ukraine for membership in the North Atlantic Treaty Organization »]. (n.d.). zakon.rada.gov.ua. Retrieved from https://zakon.rada.gov.ua/laws/show/92/2010\#Text [in Ukrainian].

12. Ukaz Prezidenta Ukraïni « Pro zatverdzhennja Richnoï nacional'noï programi spivrobitnictva Ukraïna-NATO na 2011 rik », [Decree of the President of Ukraine « On approval of the Annual National Program of Ukraine-NATO Cooperation for 2011 »]. (n.d.). zakon.rada.gov.ua. Retrieved from https://zakon.rada.gov.ua/laws/show/468/2011\#Text [in Ukrainian].

13. Ukaz Prezidenta Ukraïni «Pro Nacional'nu strategiju rozvitku osviti v Ukraïni na period do 2021 roku », [Decree of the President of Ukraine « On the National Strategy for the Development of Education in Ukraine for the period up to 2021 »]. (n.d.). zakon.rada.gov.ua. Retrieved from https://zakon.rada.gov.ua/laws/show/344/2013\#Text [in Ukrainian].

14. Ukaz Prezidenta Ukraïni «Pitannja golovnogo organu vijs'kovogo upravlinnja Nacional'noï gvardiï Ukraïni », [Decree of the President of Ukraine « Issues of the main body of military management of the National Guard of Ukraine »]. (n.d.). zakon.rada.gov.ua. Retrieved from https://zakon.rada.gov.ua/laws/show/346/2014\#Text [in Ukrainian].

15. Ukaz Prezidenta Ukraïni «Pro vnesennja zmin do dejakih ukaziv Prezidenta Ukraïni», [Decree of the President of Ukraine «On Amendments to Certain Decrees of the President of Ukraine»]. (n.d.). zakon.rada.gov.ua. Retrieved from https://zakon.rada.gov.ua/laws/show/934/ 2014\#Text [in Ukrainian].

16. Ukaz Prezidenta Ukraïni «Pro zahodi z vidznachennja u 2015 roci 70-ï richnici Peremogi nad nacizmom u Evropi ta 70-ï richnici zavershennja drugoï svitovoï vijni », [Decree of the President of Ukraine « On measures to commemorate in 2015 the 70th anniversary of the Victory over Nazism in Europe and the 70th anniversary of the end of World War II »]. (n.d.). president.gov.ua. Retrieved from https://www.president.gov.ua/documents/1692015-18657 [in Ukrainian].

17. Ukaz Prezidenta Ukraïni «Pro zahodi shhodo polipshennja nacional'no-patriotichnogo vihovannja ditej ta molodi », [Decree of the President of Ukraine « On measures to improve the national-patriotic education of children and youth »]. (n.d.). zakon.rada.gov.ua. Retrieved from https://zakon.rada.gov.ua/laws/show/334/2015\#Text [in Ukrainian].

18. Ukaz Prezidenta Ukraïni «Pro Strategiju nacional'no-patriotichnogo vihovannja », [Decree of the President of Ukraine «On the Strategy of National-Patriotic Education »]. (n.d.). president.gov.ua. Retrieved from https://www.president.gov.ua/documents/2862019-27025 [in Ukrainian].

19. Postanova Verhovnoï Radi Ukraïni «Pro rekomendaciï parlaments'kih sluhan' z pitan' praktichnoï dijal'nosti organiv vikonavchoï vladi i organiv miscevogo samovrjaduvannja shhodo realizaciï zakonodavstva u sferi molodizhnoï politiki», [Resolution of the Verkhovna Rada of Ukraine "On Recommendations of Parliamentary Hearings on the Practical Activities of Executive Bodies and Local Self-Government Bodies Concerning the Implementation of Legislation in the Sphere of Youth Policy"] (n.d.). zakon.rada.gov.ua. Retrieved from https://zakon.rada.gov.ua/laws/show/822-14\#Text [in Ukrainian].

20. Zakon Ukrainy « Pro pozashkil'nu osvitu »[The Law of Ukraine « On Extracurricular Education »]. (n.d.). zakon.rada.gov.ua. Retrieved from https://zakon.rada.gov.ua/laws/show/184114\#Text [in Ukrainian].

21. Postanova Verhovnoï Radi Ukraïni «Pro zahodi Kabinetu Ministriv Ukraïni shhodo zahistu nacional'nih interesiv derzhavi u sferah nacional'no svidomogo i patriotichnogo vihovannja molodogo pokolinnja ta zabezpechennja jogo rozvitku» [Resolution of the Verkhovna Rada of Ukraine «On Measures of the Cabinet of Ministers of Ukraine on Protection of National Interests of the State in the Spheres of Nationally Conscious and Patriotic Education of the Young Generation and Ensuring Its Development»] (n.d.). zakon.rada.gov.ua. Retrieved from https://zakon.rada.gov.ua/laws/show/865IV\#Text [in Ukrainian].

22. Postanova Verhovnoï Radi Ukraïni «Pro 85-tu richnicju VLKSM ta derzhavnu pidtrimku molodizhnogo ruhu» [Resolution of the Verkhovna Rada of Ukraine «On the 85th anniversary of the 
Komsomol and state support of the youth movement»] (n.d.). zakon.rada.gov.ua. Retrieved from https://zakon.rada.gov.ua/laws/show/1200-IV\#Text [in Ukrainian].

23. Zakon Ukrainy «Pro Zagal'noderzhavnu programu pidtrimki molodi na 2004-2008 roki » [The Law of Ukraine " On the National Youth Support Program for 2004-2008 »]. (n.d.). zakon.rada.gov.ua. Retrieved from https://zakon.rada.gov.ua/laws/show/1281-15 [in Ukrainian].

24. Postanova Verhovnoï Radi Ukraïni « Pro rekomendaciï parlamens'kih sluhan' pro stanovishhe molodi v Ukraïni (shhodo pidtrimki molodoï sim’ï, posilennja social'nogo zahistu ditej ta molodi u 2001-2006 rokah)» [Resolution of the Verkhovna Rada of Ukraine « On Recommendations of Parliamentary Hearings on the Situation of Youth in Ukraine (on Support of Young Families, Strengthening Social Protection of Children and Youth in 2001-2006)»] (n.d.). zakon.rada.gov.ua. Retrieved from https://zakon.rada.gov.ua/laws/show/816-V\#Text [in Ukrainian].

25. Postanova Verhovnoï Radi Ukraïni « Pro Rekomendaciï parlaments'kih sluhan' pro stanovishhe molodi v Ukraïni «Molod' ta zdorovij sposib zhittja»» [Resolution of the Verkhovna Rada of Ukraine « "On Recommendations of Parliamentary Hearings on the Situation of Youth in Ukraine" Youth and Healthy Lifestyle "»] (n.d.). zakon.rada.gov.ua. Retrieved from https://zakon.rada.gov.ua/laws/show/2992-VI\#Text [in Ukrainian].

26. Zakon Ukrainy « Pro vishhu osvitu » [The Law of Ukraine « On Higher Education »]. (n.d.). zakon.rada.gov.ua. Retrieved from https://zakon.rada.gov.ua/laws/show/1556-18 [in Ukrainian].

27. Postanova Verhovnoï Radi Ukraïni «Pro vshanuvannja geroïv ATO ta vdoskonalennja nacional'no-patriotichnogo vihovannja ditej ta molodi » [Resolution of the Verkhovna Rada of Ukraine « $\mathrm{n}$ honoring the heroes of the ATO and improving the national-patriotic education of children and youth »] (n.d.). zakon.rada.gov.ua. Retrieved from https://zakon.rada.gov.ua/laws/show/373-19\#Text [in Ukrainian].

28. Postanova Verhovnoï Radi Ukraïni Pro Rekomendaciï parlaments'kih sluhan' pro stanovishhe molodi v Ukraïni na temu: «Cinnisni orientaciï suchasnoï ukraïns'koï molodi» » [Resolution of the Verkhovna Rada of Ukraine «On Recommendations of Parliamentary Hearings on the Situation of Youth in Ukraine on the Subject:" Value Orientations of Modern Ukrainian Youth "»] (n.d.). zakon.rada.gov.ua. Retrieved from https://zakon.rada.gov.ua/laws/show/1908-19\#Text [in Ukrainian].

29. https://sluga-narodu.com/program/.

30. https://zagittya.com.ua/ua/page/programma.html

31. https://ba.org.ua/programm/

32. https://eurosolidarity.org/wp-content/uploads/2020/02/Programa_31_05_2019.pdf

33. https://goloszmin.org/program

34. https://zamajbutne.com.ual

35. Postanova Kabinetu Ministriv «Pro utvorennja Mizhvidomchoï komisiï z pitan' nacional'nopatriotichnogo vihovannja» [Resolution of the Cabinet of Ministers of Ukraine "On the establishment of the Interdepartmental Commission on National-Patriotic Education".] (n.d.). zakon.rada.gov.ua. Retrieved from https://zakon.rada.gov.ua/laws/show/524-2015-п\#Text [in Ukrainian].

36. Rozporjadzhennja Kabinetu Ministriv Ukraïni «Pro zatverdzhennja zahodiv shhodo nacional'no-patriotichnogo vihovannja molodi na 2016 rik» [Order of the Cabinet of Ministers of Ukraine "On approval of measures for national-patriotic education of youth for 2016."] (n.d.). zakon.rada.gov.ua. Retrieved from https://zakon.rada.gov.ua/laws/show/524-2015-п\#Text [in Ukrainian].

37. Rozporjadzhennja Kabinetu Ministriv Ukraïni «Pro zatverdzhennja planu zahodiv shhodo nacional'no-patriotichnogo vihovannja molodi na 2017 rik » [Order of the Cabinet of Ministers of Ukraine " On approval of the action plan for national-patriotic education of youth for 2017 "] (n.d.). zakon.rada.gov.ua. Retrieved from https://zakon.rada.gov.ua/laws/show/898-2016-p\#Text [in Ukrainian].

38. Postanova Kabinetu Ministriv «Pro zatverdzhennja Tipovogo polozhennja pro koordinacijnu radu z pitan' nacional'no-patriotichnogo vihovannja pri miscevij derzhavnij administraciï » [Resolution of the Cabinet of Ministers of Ukraine " On approval of the Standard Regulations on the Coordinating Council for National-Patriotic Education at the local state 
administration ".] (n.d.). zakon.rada.gov.ua. Retrieved from https://zakon.rada.gov.ua/laws/show/9992016-п\#Text [in Ukrainian].

39. Postanova Kabinetu Ministriv «Pro zatverdzhennja planu dij shhodo realizaciï Strategiï nacional'no-patriotichnogo vihovannja na 2020-2025 roki » [Resolution of the Cabinet of Ministers of Ukraine " On approval of the action plan for the implementation of the Strategy of national-patriotic education for 2020-2025 ".] (n.d.). zakon.rada.gov.ua. Retrieved from https://zakon.rada.gov.ua/laws/show/ 932-2020- п\#Text [in Ukrainian].

40. Rozporjadzhennja Kabinetu Ministriv Ukraïni «Pro shvalennja koncepciï Derzhavnoï cil'ovoï social'noï programi nacional'no-patriotichnogo vihovannja na period do 2025 roku » [Order of the Cabinet of Ministers of Ukraine " On approval of the concept of the State target social program of national-patriotic education for the period up to 2025 "] (n.d.). zakon.rada.gov.ua. Retrieved from https://zakon.rada.gov.ua/laws/show/1233-2020-p\#Text [in Ukrainian]. 